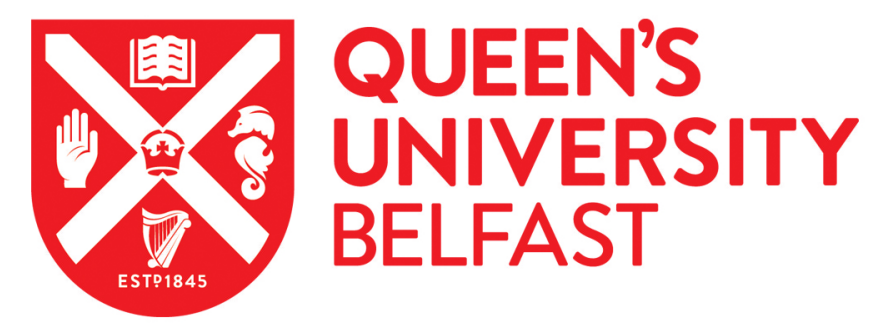

\title{
Collective bargaining and unpaid care as social security risk - an EU perspective
}

Schiek, D. (2020). Collective bargaining and unpaid care as social security risk - an EU perspective. International Journal of Comparative Labour Law and Industrial Relations, 36(3), 387-408.

http://www.qub.ac.uk/research-centres/centre-european-transnational-studies/

\section{Published in:}

International Journal of Comparative Labour Law and Industrial Relations

\section{Document Version:}

Peer reviewed version

\section{Queen's University Belfast - Research Portal:}

Link to publication record in Queen's University Belfast Research Portal

\section{Publisher rights}

Copyright 2020 Kluwer Law International. This work is made available online in accordance with the publisher's policies. Please refer to any applicable terms of use of the publisher.

\section{General rights}

Copyright for the publications made accessible via the Queen's University Belfast Research Portal is retained by the author(s) and / or other copyright owners and it is a condition of accessing these publications that users recognise and abide by the legal requirements associated with these rights.

Take down policy

The Research Portal is Queen's institutional repository that provides access to Queen's research output. Every effort has been made to ensure that content in the Research Portal does not infringe any person's rights, or applicable UK laws. If you discover content in the Research Portal that you believe breaches copyright or violates any law, please contact openaccess@qub.ac.uk. 


\section{European\& Transnational Studies on-line papers}

http://www.qub.ac.uk/research-centres/centre-european-transnational-studies/

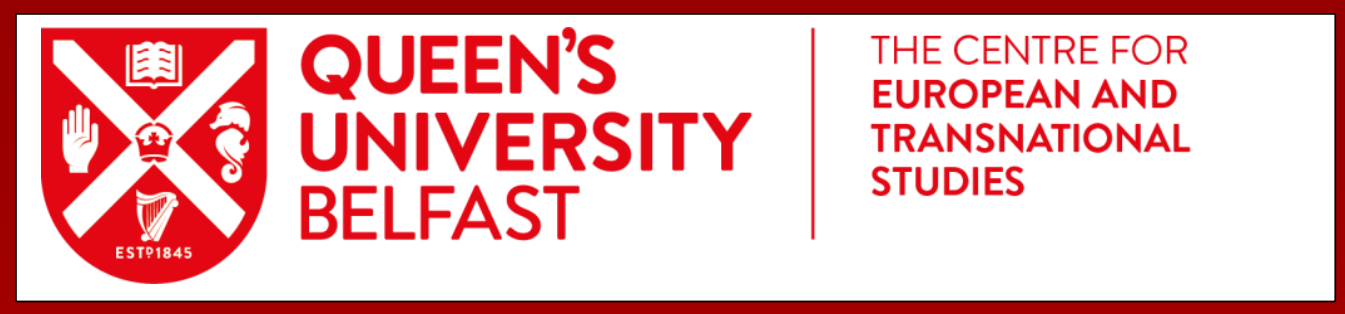

\section{DAGMAR SCHIEK}

Collective bargaining and unpaid care as a social security risk - an EU Perspective

Volume 8, Issue 1, 2020

These on-line papers are part of the programme provided under the Jean Monnet ad Personam Chair held by Dagmar Schiek, which was part-funded by the EU Commission from September 2011 to August 2014 (University of Leeds)

This paper is pre-edited work that has been accepted for publication in the IJCLLIR. 


\title{
Collective bargaining and unpaid care as social security risk - an EU perspective
}

\section{Dagmar Schiek*}

\begin{abstract}
This article contributes to the debate on how collective agreements can enhance social security from the perspective of unpaid care work. It defines the risk of giving up employment in favour of unpaid care as a social security risk (the care risk). It analyses how collective agreements in the EU can address this risk while not compromising gender equality. This analysis is conducted with a focus on European Union law's impact on a regulatory practice yet to emerge: the inclusion of institutional (child) care provisions in collective agreements. Analysing risks emerging from EU law, we conclude that EU law is disruptive for innovative collective bargaining strategies if interpreted from a merely economic-liberal perspective.
\end{abstract}

\section{Key words}

Occupational social security \# work-life balance \# EU competition law \# collectively agreed (child) care institutions \# European Union \# EU Law \#

\section{Introduction}

Policy reactions to the global Covid 19 pandemic have unexpectedly highlighted the relevance of unpaid care obligations for continued employment: closures of schools and other child-care institutions, and the ban on in-house care, has led to many parents reducing their working time or, if they are working from home, experiencing a new reality of double tasking. If anyone needed evidence, this demonstrates that the lack of care for children or elderly relatives will induce persons, frequently women, to give up or reduce paid work in favour of unpaid care work. ${ }^{1}$ Yet, the risk to lose or reduce paid employment in favour of unpaid care work is not conventionally addressed as a social security risk, and neither is it at the centre of debates on using collective agreements to provide or complement social security provision, either at sectoral or company level.

The geographical scope of the article is Europe, more specifically the European Union. Both social security and collective bargaining first developed in Europe. Collective bargaining in Europe has developed into a complex multipolar system, in which national and subnational law and practice interacts with European Union law and policy. ${ }^{2}$ The latter's role is contradictory: while in the initial phases of European integration, there was a general expectation that the Common Market would result in a European level industrial relations system, (Dunlop, 1958, p. 75; Falkner, 1998, pp. 196-7) today na-

\footnotetext{
* Professor of law, Jean Monnet ad personam Chair for EU law and policy, Queen's University Belfast, Centre for European and Transnational Studies, d.schiek@qub.ac.uk. Preparatory work for this article was presented at a workshop on the Social Partners and the Welfare State: Challenges and Opportunities (Stockholm March 2019) and at a panel at the LLRN 2019 in Valparaiso, both convened by Petra Herzfeld Olsson, whose invitation prompted me to engage with this theme. I am grateful to the convenor and the discussants and participants at those occasions. The final result also profited from valuable suggestions by Pnina Alon-Schenker and a robust anonymous referee process.

1 For first assessments on parental labour market drop-outs see (Adams-Prassl, et al., 2020; Alon, et al., 2020; Hupkau \& Perongolo, 2020; Jessen \& Waights, 2020).

2 See recently (Furåker \& Larsson, 2020).
} 
tional and sub-national industrial relations systems co-exist with EU level industrial relations in a multi-level governance scenario (Keune \& Marginsson, 2013) with increasing disruption from EU level law and policy. (González Begega \& Aranea, 2018, pp. 611-4; Marginsson, 2016, pp. 1040-1, 1045-7)

The article argues that the care-risk can be defined as a new social security risk, building on the European tradition of social security, and that it is also not beyond the reach of collective bargaining in principle. It derives from the extensive literature on "work-life balance" and gender equality, that provision of (child) care institutions is particularly suitable to addressing that risk. After establishing that there are first cautious steps to integrate the provision of child care into collective bargaining, it analyses the question whether and in how far common institutions by social partners established by collective agreements are vulnerable to challenges under EU competition and internal market law. The result confirms the hypothesis that EU economic law is disruptive for innovative collective bargaining strategies if interpreted from a merely economic-liberal perspective.

The next section contextualises the argument within debates on "work-life balance", gender equality and collectively agreed social security, identifying in how far it contributes novel concepts. Section III establishes which aspect of the care challenge can be defined as a social security risk, homing in on child care, and the provision of child care institutions as the most promising way of addressing the care risk. Section IV discusses whether addressing the (child) care risk is a suitable field for collective bargaining. Section $\mathrm{V}$ reports first attempts in European industrial relations to address the (child) care challenge, and identifies the risks emanating from EU economic law for establishing those institutions by collective agreements.

\section{Context}

\section{1. "Work life balance", unpaid care work and gender equality in employment}

The rich literature on work life balance, gender equality and the distribution of unpaid care work can only be outlined shorty. The debate on the ethics of care and working life highlights the ubiquity of caring in human interaction, and analyses how unequal responsibility for the caring aspect can cause imbalance of opportunities in any setting, including the work place. (Fineman, 2004; Herring, 2013) ${ }^{3}$ Other approaches question the ability of capitalism to integrate care (Fraser, 2016) or provide a feminist analysis of how welfare states respond to renewed care risks (Ciccia \& Sainsbury, 2018). The question whether unpaid care work should be redistributed among women and men, or replaced by paid care work as far as possible, has divided generations of feminists. ${ }^{4}$ Extremists suggest to either reserve care work for women while increasing its moral and economic appreciation or, in the other extreme, to insist that women resist the expectation to take on unpaid care work in order to improve their employability, on the other hand..$^{5}$ The middle ground is occupied by those who demand that both parents are supported by maternity/paternity and parental leave entitlement with continuity of

\footnotetext{
3 For an overview of the debate see (Caracciolo di Torella \& Masselot, 2020, pp. 44-9).

4 See for an overview from US perspectives (Williams, 2002), from European perspectives (Caracciolo di Torella \& Masselot, 2020, pp. 33-8).

5 Swedish authors represent a European variety of the latter, by openly referring to the potential loss of societal investment due to promoting housewifery: "Since women are at least as educated as men, the single breadwinner model has also led to a plethora of highly educated housewives in Europe. This is an expensive arrangement, both for society and individual families. Society invests in the education of people who then disappear from the labour market for long periods, with the attendant high risk that their knowledge will become obsolete (...) Employers will be reluctant to employ or invest in women if they assume that they will leave work as soon as they have children. The single breadwinner model also makes families more vulnerable to the risk (...) (of) unemployment and illness." (Nordström, 2015, p. 45).
} 
pay or benefits, while also being able to avail of high-quality care institutions, in order to redistribute unpaid care work evenly. (Caracciolo di Torella \& Masselot, 2020; Rubery \& Koukidiakis, 2016) ${ }^{6}$ While the policy debate on mothers' (parents') remunerated work is as old as industrial work, ${ }^{7}$ increasing longevity creates new expectations to take up unpaid elder care once children have outgrown the need of unpaid care. (Herlofson \& Brandt, 2019) These debates have recently led to new EU legislation requiring Member States to provide for unpaid leave for elder care and some benefit for paternal and parental leave as well, ${ }^{8}$ preceded and followed by intense debate. (Bouget, et al., 2017; Chieregato, 2020; Isailovic, 2020) ${ }^{9}$

This article builds on the results of those debates rather than engaging in them. The academic evidence confirms that women's lower engagement in remunerated work globally is partially due to the expectation that any woman undertakes significant amounts of unpaid care. While some hail a "shift to equal parenting" in families (Williams, et al., 2016), current statistics still unveil that any such shift is excruciatingly slow. (GED/ILOAIDS, 2018) Academic studies commissioned by the ILO, (Rubery \& Koukidiakis, 2016) and conducted by the OECD (2012) as well as policy reports for the EU (Bettio \& Sansonetti, 2015) confirm that a combination of expanding acceptable child day-care institutions and reducing the cumulated time mothers spend in maternity and parental leave will best contribute to securing women's position in paid employment. It is also necessary that acceptable institutions are available for elderly care. The difference between children and the elderly is that the latter have a long life in which they could pay into a care insurance, which can then provide access to care or refund of care costs. (Österle \& Rothgang, 2010; Pacolet, et al., 2000)

\section{Gender equality policy and collective bargaining}

Trade unions have increasingly engaged with policies on work-life balance and care. Traditionally, collective agreements have preceded or complemented legislation granting maternity leave or parental leave, occasionally with compensation for lost earnings. (Ceccon \& Ahmad, 2018)Those collective bargaining strategies attract the same criticism as legislative policies providing for maternity leave and/or parental leave: in particular US American authors underline how generous leave policies in Europe may increase female employment participation at the price of limiting women's equal access to more qualified positions. (Nordström, 2015; Orloff, 2010) Further, the ambiguity to including entitlements to request leave, part time or flexibilization of working time in collective agreements is illustrated by the position of those measures in the discourse on "flexicurity": active parents' desire to reduce pay by working less or more flexibly constitutes the main example for employees' interest in flexibility, while staff retention presents the main example of employers' interest in security. (Kongshøj Madsen, 2007) In the "flexicurity matrix" the term "combination security" indicates the gain of being able to take leave instead of giving up employment. (Marginson \& Galetto, 2016, p. 95) However, leave entitlements also induce employees to forego remunerated work in favour of providing unpaid care, thus enhancing flexibility gains of employers. (Rubery \& Hebson, 2018, p. 414) More

\footnotetext{
6 For some data supporting the suggestion that the best model consists of a combination of medium length maternity leave with full compensation for lost earnings and comprehensive provision of non-familial child care covering a full time working day plus time for commuting see (GED/ILOAIDS, 2018, pp. 83-95, 119-20).

7 The ILO recently celebrated the $100^{\text {th }}$ anniversary of the first ILO convention on maternity protection. The resulting report again recommended to increase institutional child care provision as one of the main preconditions for improved equality. (International Labour Organisation, 2019).

8 Directive (EU) 2019/1158 of the European Parliament and of the Council of 20 June 2019 on work-life balance for parents and carers, repealing Council Directive 2010/18/EU, OJ L 188/79 of 12 July 2019.

9 This debate led some to reject compulsory maternity leave as an EU law requirement (de la Corte Rodriguez, 2018).
} 
traditional collective bargaining strategies, such as limiting daily and weekly hours of paid employment, may indirectly further a fairer division of unpaid care work by enhancing every adult's opportunities to engage in unpaid care. (Eurofund, 2017) Strict limits on paid employment also remove the illusion of the "unencumbered worker", (Caracciolo di Torella \& Masselot, 2020, pp. 35-7) i.e. the idea that employees are truly free to dedicate so many hours to paid employment that no time remains to care for their own reproduction.

Pursuing gender equality through collective bargaining goes beyond reconciling paid employment and unpaid care work. Lower pay for women (often referred to as "gender pay gap") is not exclusively attributable to unpaid care. Bargaining for gender equality most certainly encompasses bargaining for equal pay, complemented or replaced by litigation strategies depending on national tradition. ${ }^{10}$ Bargaining for equality may also include agreements on specific equality plans, as required by French legislation for company level agreements. Further, bargaining for equality may include attempts to set minimum requirements for so-called atypical employment contracts. (Bosch, 2019; Courtioux \& Erhel, 2019)

Collective bargaining for gender equality is also narrower than such reconciliation. Equal pay and equal treatment are usually not pursued exclusively for those wishing to undertake unpaid care work. Addressing the desire of an increasing proportion of men to actively participate in unpaid care goes beyond gender equality, too. Establishing of child care institutions also has a wider effect on family life, as the closure of child care institutions in the current pandemic acutely demonstrates.

\section{Occupational social security as a field for collective bargaining}

"Reconciliation" is only one of the four risks addressed by occupational welfare programmes. (Natali, et al., 2018 a) Literature on the potential for collective bargaining agreements to step into any void left by welfare state entrenchment, and in particular the reduction of social insurance benefits, has been burgeoning, (De le Court, 2019; Curzi, et al., 2015; Natali, et al., 2018 a) at times stressing the potential of collective bargaining of contributing in innovative ways to inclusive growth. (Vandekerckhove, 2018)The limits drawn by EU economic freedoms and competition rules for collectively agreed pension schemes have re-emerged recently in response to the increasing relevance of occupational welfare. (Meerten \& Schmidt, 2017; Vanherle, 2019)

\section{The contribution beyond the context}

The ensuing discussion moves beyond these contextual debates. First, it presents a fresh perspective by conceptualising the care-risk from the perspective of the person who is challenged to forego remunerated work in favour of unpaid labour, while often also becoming economically dependent from familial relationships. Traditionally, the care-risk is viewed as a macro-economic risk, best avoided by activating the familial support regime potentially creating dependency. Second, it is suggested that the care-risk, once categorised as a new social security risk, can partially be addressed through collective bargaining. Resulting from the gender equality perspective summarised above, the focus is on providing care through institutions. This strategy will acquire a new urgency in the wake of the Covid19 pandemic: private care institutions may become economically untenable after prolonged closure, rendering institutions created through collective bargaining a necessary complement to provision by a strained public sector. Thirdly, the article discusses specific risks emerging from EU eco-

\footnotetext{
10 In the UK equal pay principles were first introduced through collective bargaining (Deakin, et al., 2015). On the role of strategic litigation in other countries see (Fuchs, 2013). The general impact of unionisation and collective bargaining on the gender pay gap varies (Bryson, et al., 2020).
} 
nomic laws should collective agreements establish care institutions. In the past, social security institutions established through collective agreements were challenged under EU competition and internal market law, which raises the question whether an economic-liberal interpretation of those provisions again has the potential to prevent progressive solutions to current problems.

\section{Engaging in unpaid care work as a social security risk}

Care - for children, the elderly, the ill or disabled - has not been among the social risks initially addressed by social security schemes in Europe. This section thus discusses whether the engagement in unpaid care work is correctly categorised as a social security risk.

\section{Defining social security risk}

The basic risk underlying the provision of social security at the time of industrialisation was constituted by the emergence of the non-possessing classes, who could only provide for their shelter and sustenance by engaging in paid work. (Kuhnle \& Sanders, 2010) Not being able to work due to illness, unemployment and old age thus constituted a risk to the ability to obtain shelter and sustenance. The risks of illness, unemployment and old age (as a synonym for frailty) were thus the first social security risks. Modern welfare states go beyond ensuring mere survival by protecting human dignity in a more encompassing way, (Wujczyk, 2016) aiming to ensure participation in social life, cultural activities and access to information as well. Accordingly, post-industrial social security (Aravacik, 2019; Bonoli, 2007) not only addresses the risk of losing one's income, but also wider risks related to losing one's capacity to engage in (employed) work, such as daily exchange with other adults while using abilities gained in education which are deemed to provide a useful contribution to society. These risks are addressed by payments in lieu of income, but also by providing institutions and programmes to avoid the loss of and regain access to (employed) work.

To avoid an overly complex argument, this definition of the social security risk imagines the risk of losing the capacity to engage in remunerated work as external to the employment process itself. The definition thus disregards the interrelation of conditions of employment and the realisation of risks, such as attracting an illness, having to retire early or preferring taking up unpaid care work to a less than ideal employment situation.

\section{The care risk}

Proceeding from this functional perspective, what exactly constitutes the "care risk"? Again, in a slight simplification, we disregard the person in need of care, and focus on the perspective of the potential carer. Their capacity to engage in paid work may be inhibited by taking on unpaid care work. The part of care which triggers the care risk is the task of looking after those who are unable to fill their own care needs. (Daly, 2002) While there are more aspects to care, this response to the care need requires long hours of engagement excluding engagement in other (employed) work at the same time, as well as recovery from such work. The care risk is realised if an employed person reduces or gives up their employed work in order to provide unpaid care. It is created not only by the need to provide care for children, the elderly or those with impairments, but also by the absence of care provided through paid employment by professional carers.

The classical way to address the care risk measures consists of providing leave entitlements, including maternity leave, parental leave, paternity leave, carers leave. Although only maternity leave is usually reserved to mothers, women are also overwhelmingly overrepresented among those taking parental leave and carers leave. The empirical reality that unpaid carers are female is only slightly dented by the relatively recent introduction of comparatively short periods of paternity leave, which 
is reserved for men. Leave entitlements thus balance "work and life" (or rather paid and unpaid labour) while also stabilising traditional gender role compliance by inducing mothers and daughters to replace paid employment by unpaid care of children and the elderly. Substituting unpaid care through paid care constitutes an alternative here. This alternative can take two fundamentally different forms. On the one hand, care can be provided in an institutional setting, such as a child care institution or an old people home. Those institutions can be funded privately or publicly, and this could include funding by social security contributions. On the other hand, those needing institutional support for care could be given funds enabling them to employ domestic workers in their home to provide the care alongside other homely chores, possibly supported by medical staff visiting once in a while. The latter model, sometimes dubbed "cash for care" is more typical for long term care, (Da Roit \& Gori, 2019) but it also can be found in the field of childcare. (GED/ILOAIDS, 2018, pp. 14850; Simonnazzi, et al., 2019)

As discussed above, ${ }^{11}$ medium length maternity leave entitlements accompanied by compensation of lost earnings in combination with a comprehensive network of institutions for childcare and elder care ensure the highest degree of female participation in paid work. However, it is the lack of child care institutions, or the threat of their insufficient return after the global pandemic, which requires primary attention, as leave entitlements with or without a payment component are already widely accepted.

\section{Collective bargaining and the care risk}

This section addresses the question whether and in how far the care risk can and should be addressed by collective bargaining. This is by no means a matter of course. For example, the International Labour Organisation promotes a state-centred approach to child care institutions, promoting collective bargaining for securing the rights of employed care workers only. (GED/ILOAIDS, 2018, p. 117) First, we ask whether social security provision is an adequate theme for collective agreements, or other trade union activity. Second, we ask whether addressing the care risk is also suitable for collective bargaining or other trade union activity.

\section{Collective bargaining and social security}

In industrial relations systems where trade unions emerged from benevolent and mutual societies, social security stood at the heart of collective bargaining in its initial phase. These societies used contributions of workers to support colleagues in need as they became unemployed or ill. This eventually grew into the so-called Ghent system of wholly trade-union provided unemployment insurance. ${ }^{12}$ Social insurance as emanation of "corporate self-help" (Webb \& Webb, 1902, p. 145) represented an independent function of trade unions. The "method of mutual insurance", (Webb \& Webb, 1902, pp. 152-70) also known as "service function", (Ewing, 2005) complemented collective bargaining, arbitration and legislative enaction. (Webb \& Webb, 1902, pp. 171-246, 247-78) Those functions were perhaps never fully exclusive of each other. Today, mutual insurance has blended into social insurance, which in Europe is predominantly state based. However, trade unions as well as employers' associations are involved in administration of social security institutions in many countries. (Ebbinghaus, 2010)

\footnotetext{
11 Sub II 1.

12 Social dialogue remains relevant for Belgian unemployment insurance (van Rie, et al., 2011), and in Sweden, though weakened by fragmented labour markets (Johansson, 2019).
} 
The flourishing debate on occupational social security via collective bargaining ${ }^{13}$ should not obscure the fact that occupational social security is not necessarily suitable for collective bargaining. Provided at company level, occupational social security constitutes an employer's retainment strategy. Nontransferable benefits such as pensions, health plans or child-care provision tend to disincentivise employee mobility. The resulting "welfare dualization" (Natali, et al., 2018 b, p. 437) arises from higher levels of entitlement for employees the company wishes to retain than for those viewed as dispensable. This triggers the question whether any functions of collective bargaining and collective agreements may be suitable to legitimise collective bargaining on social security.

The classical functions of trade unions, can be referred to as mitigating structural imbalances on the labour market. The combination of workers is a means to oppose the economically driven urge to subsume their lives under the aim of garnering profit. This not only serves to achieve an adequate wage / work bargain, but also ensures that workers can become involved in the organisation of work. (Bogg \& Novitz, 2014) Multi-employer collective bargaining in particular, can have other functions beyond the class conflict. Its regulatory function consists of providing rules for the work place with a sectoral, or even national dimension. (Ewing, 2005; Webb \& Webb, 1902) ${ }^{14}$ By removing the price of labour and working conditions from the inter-firm competition, collective agreements provide a level playing field for employees and employers alike, which can translate in surplus, (Traxler, 1996) or merely smoother organisation of work. Collective bargaining also offers employers and workers alike an opportunity of garnering the collective knowledge of those intimately involved in the work processes. This enables the parties of collective agreements to generate work rules that are not only socially responsible but also profitable in a sustainable way. Collective bargaining thus is a source of innovation. (Hayter, et al., 2011, pp. 238-39) Historically, many institutions of labour law have started out as clauses of collective agreements, and their innovative function thus seems suitable of addressing new risks. The debate on addressing welfare retrenchment via collective bargaining also draws on this innovative function, partly seeking to reconsider how provision of welfare can be improved if it is provided with social partner involvement. (Curzi, et al., 2015; Rymkevich, 2015)

\section{Collective bargaining and the care risk}

The care risk's close relationship to the gendered division of labour may induce doubt on whether it is aligned with the class-function of collective bargaining. If the risk to lose one's wage-earning capacity through unpaid care work is addressed effectively, this strengthens the position of those traditionally providing unpaid care vis a vis the other members of the family. Granting leave entitlements with some income substitution is less intrusive on the situation in the family, since unpaid care is secured alongside the former family income. This may be the reason why the predominant form of addressing the care risk through collective agreements is through leave entitlements or flexibilization of working time.

Addressing the care risk also requires the provision of remunerated care work, either in care institutions or through domestic workers, or a combination of both. Again, access to child care institutions provided by employers is viewed as on element of occupational welfare, which is often provided by employers for selected categories of employees. Providing such institutions as elements of collective agreements could avoid the differentiation and potential disciplining effect of such provision. (Curzi, et al., 2015, pp. 34, 47) After all, addressing the care risk has an element of improving working and

\footnotetext{
13 Supra sub II 3.

14 For empirical evidence for the regulatory function see (Hayter, et al., 2011).
} 
living conditions, which is the overall task of collective bargaining. Further, such agreements could draw on the innovative function of collective bargaining.

There are arguments supporting the ILO position, which favours state provision of care institutions. (GED/ILOAIDS, 2018, p. 117) For example, the interests of children or those in need of long-term care are not represented by the trade unions or employers' associations, and might thus be neglected in the collective bargaining process. On the other hand, the interests of employees encompass a good environment for those cared for, and collaboration with a variety of community institutions could contribute a further bulwark against dangers of low-quality provision. For collective agreements, the provision of paid vouchers for existing institutions, or institutions created on a communal basis constitutes a potential regulatory strategy. Care institutions could also be provided through trade unions' service functions. These are strategies which could be comprised in particular by the innovation function of collective bargaining.

\section{Care risk and collective bargaining under EU Law}

\section{Potential of EU level collective bargaining for care institutions}

EU level collective bargaining as one element of collective bargaining in Europe ${ }^{15}$ has addressed the care risk: the very first agreement between EU level organisations of management and labour was on parental leave. ${ }^{16}$ Its accelerated adoption in less than ten months exemplified the corporatist character of implementing EU level social partner agreements by Directive. ${ }^{17}$ The very modest parental leave directive was replaced by the more ambitious Work Life Balance Directive, ${ }^{18}$ which EU level social partners did not endorse. Management and labour at EU level could also devise model agreements on securing or establishing (child) care institutions, or on how collective agreements could and should address interim care crises arising from pandemics, which are bound to increase. However, given their reluctance around the Work-Life-Balance Directive and the recent reluctance of the EU Commission to implement EU level social partner agreements, ${ }^{19}$ it seems more fruitful to turn to national level opportunities.

\section{Steps towards care institutions via collective agreements under national law}

The suggestion that collective agreements in Europe should include commitments to provide child care institutions is not as utopian as it may seem. A study on Italy identifies the creation of social services by collective agreement as a frequent occurrence in occupational welfare, with a specific demand for child care or non-self-sufficient family members. (Ciarini \& Lucciarini, 2017, pp. 149-151) Similarly, a study on collective bargaining on social risks in the Netherlands identified a significant

\footnotetext{
15 Supra text around note 2 .

16 Framework Agreement on Parental Leave between the European Trade Union Congress (ETUC), the European Centre of Employers and Enterprises providing Public Services and Services of General Interest (CEEP) and the Union of Industrial and Employers' Confederations of Europe (UNICE, since succeeded by BUSINESSEUROPE) of 14 December 1995, revised by Framework Agreement on Parental Leave of 18th June 2009, by BUSINESSEUROPE, UEAPME (Union Européenne de l'Artisanat et des Petites et Moyennes Entreprises), CEEP and ETUC, implemented as a Community law instrument by Council Directive 96/34/EC of 3 June 1996 on the framework agreement on parental leave concluded by UNICE, CEEP and ETUC, OJ L 145, 19.6.1996, p. 4-9; initially superseded by c Council Directive 2010/18/EU of 8 March 2010 implementing the revised Framework Agreement on parental leave ; OJ L 68, 18.3.2010, p. 13-20.

17 (Falkner, 2000), for the differentiation between corporatist and autonomous route see (Schiek, 2016, pp. 292-308).

18 Supra note 8.

19 See (Dorssemont \& Lörcher, 2019) for the documentation on the EU Commission's refusal to implement a European social partner agreement on occupational health for hair dressers.
} 
number of collective agreements providing childcare institutions - before employers were under a statutory obligation to contribute to childcare. (Yerkes \& Tijdens, 2010, pp. 375-9) These are cautious steps, and the main instruments in collective agreements to respond to care needs consist of working time rules, options to work part time or be leave entitlements in more expansive measure than required by legislation. These main instruments constitute a risk to gender equality at work, though.

\section{Potential barriers under EU law}

EU law is relatively neutral on collective agreements relating to working time, including limits to daily and weekly working time in order to allow all adults to contribute to informal care work. While an isolated court found a violation of a national ban on cartels by strict limits on working time in the banking sector ${ }^{20}$ such an approach is not mirrored by ECJ case law. Neither are there any indications that collective agreements on leave entitlements or bonus payments enabling carers to source care ("cash for care") would be affected. However, the risks emanating from EU economic law intensify if collective agreements establish social security institutions.

The next paragraphs summarise the relevant case law and outline the risks emerging if it would be continued. Subsequently, an alternative reading of EU economic law is developed, based on the constitutional values underpinning the EU.

\section{a) Collectively agreed common institutions in EU economic law-current and evolving case law}

Nearly all the core case law on EU competition law and collective agreements evolved around common institutions of the social partners established by collective agreements, more specifically sectoral pension and health care funds. ${ }^{21}$ EU competition law comprises a ban on cartels (Article 101 TFEU) and of an abuse of a dominant market position (Article 102 TFEU), as well as a ban on state aid (Article 107 TFEU), though the latter has not been applied to collective bargaining agreements yet and shall be neglected. ${ }^{22}$ State endorsement of collective agreements, in the form of an extension for general application, may constitute a violation of Article 4(3) TEU in conjunction with Article 101 or 102 TFEU. ECJ case law has carved out a limited exclusion for collective labour agreements from Article 101 TFEU, but not from Article 102 TFEU, though some social security institutions where exempted from the scope of Article 102 as services in the general economic interest (Article 106(2) TFEU).

The ECJ first established that employees (or their associations) do not constitute undertakings, ${ }^{23}$ thus preventing a full doctrinal return to the times when ring-fencing agreements between workers as well as agreements between collectives of workers and individual employers or their organisations were criminalised. ${ }^{24}$ However, the EU anti-trust clause, Article 101 TFEU, remains relevant for sec-

\footnotetext{
20 For example, KG (Berlin) 21 February 1990, U 4357/89, AP 60 to Article 9 GG (short English summary in Dagmar Schiek et al, EU Social and Labour Rights and EU Internal Market Law (European Parliament 2015), 38.

21 For more detail see (Schiek, et al., 2015, pp. 35-44); for references to the extensive discussion on the Dutch occupational pension system under EU competition law see (Vanherle, 2019, pp. 8-17).

$22 \mathrm{~A}$ pending case on the privatisation of the Slovak health insurance system may provide indirect indications on the matter (Opinion of AG Pikamäe of 19 December 2019, Case C-262, 271/18 P COM and Slovak Republic v Dôvera zdravotná poist'ovňa, EU:C:2019:1144).

23 Case C-22/98 Becu EU:C:1999:419, paragraphs 26-27, on the question whether transport undertakings using Ghent harbour could be required by law to use recognised dock workers, whose wages were set by collective agreement, which also defined the notion of registered dock workers.

24 Examples include the British Combination Act 1799, which stated that "all contracts, covenants and agreements (....) made between any journeymen, manufacturers or other persons (...) for obtaining an advance of wages (...) or altering their usual hours or time of working" were "illegal, null and void". Similarly, the Loi de Chapelier prescribed that "it is contrary to the (...) Constitution for citizens with the same profession s (...) to (..) make agreements among themselves
} 
toral collective agreements. These equalise some of the parameters on which employers could compete as economic actors, enabling courts to classify the employers' associations' signature under the collective agreement as a decision of an association of undertakings under Article 101 TFEU. In a series of judgments in 1999 rulings, ${ }^{25}$ the ECJ has embraced this view. Instead of exempting collective bargaining generally from the application of competition law, ${ }^{26}$ it established a limited exclusion from Article 101 TFEU for collective agreements between trade unions and employers or their associations, known as Albany exclusion. ${ }^{27}$ Accordingly, collective agreements do not fall under Article 101 TFEU ins so far as they pursued certain social policy aims. Initially this was justified by reference to overall social aims of the Treaties and their explicit recognition of collective bargaining (today Articles 3, 152, 154, 155 TFEU). ${ }^{28}$ The 2011 AGR2 ruling specified those social objectives as "intended to improve employment and working conditions". ${ }^{29}$ Thus, the Court has recognised that providing protection against the classical social security risks also improves employment and working conditions, leading to those collective agreements being excluded from the ban on cartels under EU law.

Nevertheless, there is a risk that common institutions established through collective agreement are classed as cartel under Article 101 TFEU. This is illustrated by the EFTA Court's Holship ruling of 2016. This concerns the activities of the Administration Office (AO), a pooling agency for dockworkers in a Norwegian port established by collective agreement. In line with ILO Convention No 137, the AO was tasked with ensuring that the priority engagement of dock workers registered with them was complied with in line with the collective agreement, by employing dock workers and taking on more on temporary contracts if necessary. The EFTA court held that, due to a "combination of a business objective with NFT's core task as a trade union" deriving from its engagement "in the management of an undertaking" the priority clause as well as the creation of the common institution were "not (...) limited to the establishment or improvement of working conditions of the workers (...) and go beyond the ore object and elements of collective bargaining". 30 This reasoning would subject any common institution of trade unions and employer associations, as well as institutions run by trade unions, to the ban on cartels, if that institution does qualify as an establishment under EU competition law. The Court of Justice will soon have the opportunity to engage with the EFTA's opinion in the Holship case: two cases are pending before the Court on the current installation of the Belgian Dockers' scheme. ${ }^{31}$ The challenge focuses on freedom to provide services, which the claimants perceive as unjustifiably restricted by an obligation to use only registered dock-workers for docking activities in the harbours of Zeebrugge and Antwerp. The collective agreement in question has been extended for general application, and it too establishes a dock-worker pooling institution. ${ }^{32}$ Thus, should the

designed to set prices for their (...) labour", adding that any such agreements "will be declared unconstitutional and void".

25 Case C-67/96 Albany EU:C:1999:430; Case C-115-117/97 Brentjens EU:C:1999:434; Case C-219/97 Drijvende Bokken EU:C:1999:437.

26 This is suggested in (Directorate for Financial and Enterprise Affairs, Competition Committee, 2019, p. 8).

27 The Court later confirmed that this exclusion only applied to collective agreements concluded in favour of workers, including those falsely declared as self-employed (Case C-413/13 FNV KIEM EU:C:2014:2411). This is relevant for the potential to conclude collective agreements for own-account workers including those working in the "gig industry" (Schiek \& Gideon, 2018), and has recently been questioned in the light of the European Committee of Social Rights decision No 123/2016 (12 Dec 2018) on a complaint against former Irish legislation excluding self-employed workers from collective bargaining rights (Doherty \& Franca, 2019). This problem is not addressed here.

28 ECJ Albany, supra n25, paragraph 60.

29 Case C-437/09 AG2R Prévoyance EU:C:2011:112, paragraph 29.

30 EFTA case E-14/15, Holship, paragraph 49-50, see also (Hendy \& Novitz, 2019 ).

31 The case numbers of these references are C-407/19 and C-471/19, none is scheduled for a hearing yet.

32 On the principles underlying the organisation of dock work see (Van Hiel, 2017; Verhoeven, 2011) (Verhoeven, 2011). 
ECJ follow the EFTA Court for once, the establishment of common institutions by collective agreement would risk attracting the wrath of competition authorities.

Furthermore, even if a collective agreements is excluded from Article 101 TFEU, a social security institution established by the same collective agreement could still obtain a dominant market position and abuse it, thus violating Article 102 TFEU. It may escape that control if it is not an undertaking under EU competition law. Under the functional notion of an undertaking a public or non-profit organisation can be an undertaking if engaging on the same market as for-profit organisations. As most social security provisions are also provided by private insurance or institutions (such as hospitals), social security institutions would normally constitute undertakings. An exception applies if they are organised on the basis of solidarity and also are under state supervision. The first condition is fulfilled if the institution provides benefits irrespective of the contributions paid, as is typical for social insurance. A pension fund or health care fund which has been established by collective agreement can fall under state supervision, if the collective agreement is extended for general application and the same time the institution is integrated into the compulsory national social insurance. As soon as there is an element of choice, the institution might remain an undertaking. For example, in the AGR2 case, the parties to the collective agreement could have decided to replace the providence fund as a manager of their health insurance system, which was the reason why the Court assumed that they might be an undertaking. ${ }^{33}$ The health care fund was classified as an institution providing services of general economic interest under Article 106(2) TFEU, for which reason the extension of the collective agreement for general application did not violate Article 102 TFEU in conjunction with Article 106(1) TFEU. ${ }^{34}$ Unsurprisingly, the EFTA court in the Holship case found that the AO constituted an undertaking, though the referring court had not sufficiently investigated the facts of the case in order to find or exclude a dominant market position and an abuse of that position. ${ }^{35}$

Since the risks emerging from Article 102 TFEU have been overcome in a number of cases, litigants have taken to using Article 56 TFEU (freedom of services) or Article 52 (freedom of establishment) as an alternative route. This was encouraged by the now infamous Laval quartet, ${ }^{36}$ in which the Court held that there is no collective bargaining exclusion from the economic freedoms. The first case applying this to a collective agreement on occupational social security was decided in 2010. It related to the question whether a collective agreement could specify the institution suitable to supervise a third-pillar pension scheme. While the Court answered in the negative, ${ }^{37}$ the AG opinion developed an argument coining future case law: the autonomy of the partners of a collective agreement would not be impacted upon by subjecting them to an obligation to conduct a public procurement procedure, and to provide transparency in relation to the criteria decisive for becoming the trustee of the third pillar pension fund. ${ }^{38}$ The 2015 UNIS case specified those conditions in relation to occupational health care. The Court had to answer a reference question by the French Conseil d'État on whether a collective agreement extended for general application could impose one provider for occupational

\footnotetext{
33 Supra $\mathrm{n} 29$, paragraphs 40-65 with reference to former case law.

34 Paragraphs 73-80.

35 Supra $n$ 30, paragraphs 84-100.

36 This term refers to four rulings of the Court which related to posted workers and protection of wages under national collective agreements and/or legislation (Case C-341/05 Laval EU:C:2007:809; Case C-438/05 ITWF V Viking, EU:C:2007:772, Case C-346/06 Rüffert EU:C:2008:189, judgment of 19 June 2008 COM v Lux C-319/06 EU:C:2008:350.

37 Case C-271/08, COM v Germany, EU:C:2010:426, confirmed recently in case C-699/17 Allianz Vorsorgekasse AG EU:C:2019:290.

38 Opinion of 14 April 2010, EU:C:2010:183, paragraphs 200-230, on transparency paragraphs 215-220.
} 
health care on all artisan bakeries in a region. The ECJ found parallels to the Albany situation: in both cases, a collective agreement created a social security institution. Once the collective agreement was extended for general application, that body "acquires an exclusive right" ${ }^{39}$ Transferring principles developed in public procurement law, the Court concluded that an obligation to maintain transparency must be complied with: the public authority (not the partners of the collective agreement) would have to give potentially interested economic actors the opportunity to become the institution chosen by the social partners. Thus, once an extension of the collective agreement is applied for, the social partners no longer can maintain the institution they have created. Again, the EFTA Court in its Holship ruling, proposed a slightly stricter limitation of collective bargaining rights: a trade union attempting to ensure that a Norwegian branch of a Danish company complies with Norwegian collective agreements constitutes a restriction of freedom of establishment. This is in spite of the fact that those establishing in another EEA state can be expected to integrate into the local legal frameworks. While the Court found that the national court might find a justification in favour of the dock worker pooling, it established extremely strict requirements for such a justification. ${ }^{40}$

\section{b) How does this apply to establishing care institutions in collective agreements?}

Should collective agreements establish child care institutions for certain sectors, it is by no means certain that these would be encompassed by the "Albany exception", as the case law stands. While competition lawyers find it "straight forward" to establish whether a collective agreement promotes the improvement of employment and working conditions, (Nordling, 2015) there is a raft of hidden disagreement behind that alleged clarity. An approach more aligned with traditional notions of competition law would only extend the exception to such clauses which do not impact on the interests of market participants other than employees. ${ }^{41}$ By contrast, a labour law approach would align with a wider notion of employment and working conditions, encompassing clauses regulating the composition of products, the choice of suppliers and even clauses stipulating that suppliers subject to collective agreements or honour environmental norms. (Schiek \& Ulber, 2016, p. 197) The arguments provided above for accepting the care-risk as a social security risk would support categorising the provision of care institutions by collective agreements as clauses improving employment and working conditions. However, care institutions do not only benefit the workers, but also third parties. Under a traditional competition law approach these are remote from working conditions. There is thus the risk that the Court would not view these as encompassed by the "Albany exception".

The provision of childcare institutions as common institutions on the basis of a collective agreement could also be challenged under Articles 102, 106 TFEU. If a collective agreement is extended for general application, and the choice of childcare services for parents and employers is limited as a result, such arguments might succeed in subjecting the collective agreement to the control by competition authorities. In any case, a childcare or other care institution would, even if commonly administered by trade unions and employer associations, almost certainly constitute an undertaking: care is big business, and the access of those covered by a collective agreement equals a membership construction in the private sector. An abuse of a dominant market position would only emerge if the care facilities acquire a dominant market position, which seems a utopian perspective presently.

\footnotetext{
39 Case C-25 \& 26/14, UNIS \& Beaudout Père et Fils SARL, EU:C:2015:821, paragraph 34, with reference to Albany (supra n. 25), paragraph 90.

40 Supra $n$ 30, paragraphs 115-130.

41 See AG Jacobs in his opinion on Case C-67/96, Albany, EU:C:1999:28, paragraph 43.
} 
As discussed above, this could lead to attacking the provision as a violation of freedom to provide services. If collective agreements establish care institutions for the use of employees in certain sectors, an argument might be raised that service provision by other care institutions headquartered in other Member States would be made less attractive. In a similar fashion as in COM v Germany and UNIS, ${ }^{42}$ an argument could be made that the powers of the parties to a collective agreement did not include establishing or choosing a certain institution, but only allowed a process to be established to allow bidding for care provision. Whether such a claim would be raised would obviously depend on either the Commission taking the matter in their own hands or a chain of care providers challenging their exclusion from a certain market.

All these consequences could be avoided if collective agreements on mitigating the care risk would provide only allocation rights in care institutions provided by third parties, which are not controlled by the parties to the collective agreements. This however presupposes a reality in which collective agreements are no longer necessary to address the care risk because the public and private sector provide sufficient care institutions.

Thus, in a realistic scenario, the regulation modes addressing the care risk which are most effective from a gender equality perspective are also under the highest risk of challenge under EU economic law.

\section{c) Alternative future directions}

These problems could be overcome, if the Court would reconsider its case law on the relationship of EU economic law and collective agreements, in order to align it with human rights guarantees of collective bargaining. The relevance of human rights guarantees has increased since 1999 with the Charter of Fundamental Rights of the European Union becoming legally binding in 2009. The CFREU guarantees freedom of association in Article 12, and collective bargaining rights specifically in Article 28. Since Article 12 CFREU is not conditioned by a reference to the rights specification in the Treaty, and also mirrors Article $11 \mathrm{ECHR}$, collective labour rights are guaranteed in the strongest possible form. (Schiek, et al., 2015, pp. 83-89) Conversely, competition law is not encompassed by human rights guarantees, while the CFREU mirrors the guarantee of economic freedoms in Articles 15 and 16. Both these Articles guarantee free movement rights and rights to conduct a business only in line with Treaty rights and other guarantees.

Within the categories of competition law, the autonomy of collective bargaining as required by these human rights guarantees can be achieved in two ways. First, as regards Article 101 TFEU, the construct of ancillary constraints would allow aligning traditional competition law categories with those guarantees. After all, collective bargaining agreements are necessary in order to allow workers to achieve acceptable working conditions in a self-organised way. The correlative agreement between employers is necessary to achieve such an aim, in other words, "the consequential effects restrictive of competition are inherent in the pursuit of those objectives," as the Court stated in the Wouters case, relating to a regulation by the Dutch Bar Association. ${ }^{43}$ Any anti-competitive effects of the collective agreement would constitute ancillary restraints. Such an approach would be the most elegant way to achieve the immunity of collective labour agreements from competition law, without excluding that competition authorities pursue the abusive circumvention of the ban of cartels and abuse by

\footnotetext{
42 Supra notes 37 and 39.

43 Judgment of 19 February 2002 Wouters C-309/99 [2002] ECR I-1577 EU:C:2002:98, paragraph 97; confirmed in judgment of 18 July 2006 Meca Medina C-519/04 P, EU:C:2006:492, paragraph 45.
} 
utilising collective agreements. (Lianos, et al., 2019, p. 306; Schiek, et al., 2015, p. 37) Turning to Article 102 in conjunction with Article 106 TFEU, the reference to solidarity allows an interpretation which also safeguards human rights requirements. As regards limits emanating from economic freedoms, these have been widely debated ever since the Laval quartet: ${ }^{44}$ after the Charter of Fundamental Rights for the European Union (CFREU) became legally binding, a constitutional interpretation of economic freedoms should prevail. Since rights derived from freedom of association (Article 12 CFREU) are guaranteed unconditionally, these rights condition the use of free movement rights (Article 15 CFREU) and the freedom to conduct a business (Article 16 CFREU). Under Union law, business must be conducted in a way that presupposes freedom of association and related rights, such as concluding collective agreements. Protecting collective bargaining rights would not just become an afterthought in justifying a restriction of economic freedoms. Instead, the economic freedoms would be interpreted in such ways that collective agreements cannot restrict them, except if the collective agreement is abused for limiting economic freedoms.

\section{Conclusion}

Our deliberations confirm that it is not easy to address the care risk as a novel and complex social security risk through collective bargaining, even in a relatively prosperous region such as the EU Member States. There are considerable hurdles emanating from the practice of collective agreements: while the limitation of working time is a traditional field of collective bargaining, strict limitations which are necessary to allow a true balance of employed work and informal care have been abandoned by social partners all over the world. Traditionally, collective agreements address the care risk by providing for long leave entitlements, which are at best weakly compensated. In practice, these means to steer unpaid carers (predominantly women) away from paid employment once care needs arise. Addressing the regular care risk for employees in ways also promoting gender equality in employment, however, presupposes creating reliable care institutions, possibly adapted to sector specific working time requirements. In the absence of sufficient public and private child care in many EU Member States, common institutions established via collective agreements would constitute a respite for active carers, which would seem to become ever more important with the expected decline of existing (child) care institutions following their prolonged closure in the Covid 19 pandemic.

In the EU, legal risks from its competition rules as well as the economic freedoms may arise, similar to the risks experienced by agencies pooling dock work. These risks could be overcome by a modern interpretation of EU economic law, based on the enhanced position of human rights guarantees and social guarantees in the EU Treaties from 2009. However, if a merely economic-liberal perspective on EU competition law and economic freedoms prevails, these rules would once again prove disruptive for collective bargaining, compromising innovative responses to the care risk through collective agreements, at a time when the care risk increases in the wake of a global pandemic.

The alternative interpretation of EU economic law in line with human rights guarantees and the EU's social values is required not only in response to IT driven developments, but also in response to risks as old as the care risk. The latter requires an interpretation which revives the idea that collective agreements can regulate the employment relationship beyond the wage bargain. Expanding the field of engagement for collective agreements will have positive repercussions for other areas, such as the link between working life and environmental protection, or a holistic approach to resilience against

\footnotetext{
${ }^{44}$ See for a summary (Schiek, 2017).
} 
recurrent pandemics. There is no easy way forward to addressing a novel and complex social security risk such as the care risk through collective bargaining, especially if labouring under EU law. However, forging ways forward is rewarding beyond the field of caring for others.

\section{Bibliography}

Adams-Prassl, A., Boneva, T., Golin, M. \& Rauh, C., 2020. Inequality in the Impact of the Coronavirus Shock: Evidence from Real Time Surveys. IZA Discussion Paper.

Alon, T. M., Doepke, M., Olmstead-Rumsey, J. \& Tertilt, M., 2020. The Impact of Covid 19 on Gender Equality. NBER Working Paper Series.

Aravacik, E. D., 2019. Social Policy and the Welfare State. In: B. Açıkgöz, ed. Public Economics and Finance. London: InTechOpen.

Bettio, F. \& Sansonetti, S., 2015. Visions for Gender Equality. Brussels : European Commission.

Bogg, A. \& Novitz, T., 2014. Voices at Work. Continuity and Change in the Common Law World. Oxford: Oxford University Press.

Bonoli, G., 2007. Time Matters. Postindustrialization, New Social Risks, and Welfare State Adaptation in Advanced Industrial Democracies. Comparative Political Studies, 40(5), pp. 495520.

Bosch, G., 2019. Does the German social model support the convergence of living conditions in the EU?. In: D. Vaughan-Whitehead, ed. Towards Convergence in Europe. Institutions, Labour and Industrial Relations. Cheltenham: Edward Elgar, pp. 139-174.

Bouget, D., Saraceno, C. \& Spasova, S., 2017. Towards New Work-Life Balance. Policies for those caring for Dependent Relatives. In: B. Vanhercke, S. Sabato \& D. Bouget, eds. Social Policy in the European Union: State of Play 2017. Brussels: European Trade Union Institute , p. 155-179.

Bryson, A., Dale-Olsen, H. \& Nergaard, K., 2020. Gender differences in the union wage premium? A comparative case study. European Journal of Industrial Relations, 26(2), pp. 173-190.

Caracciolo di Torella, E. \& Masselot, A., 2020. Caring Responsiblities in EU Law and Policy. New York: Routledge .

Ceccon, D. \& Ahmad, I., 2018. Do collective bargaining agreements increase equality and promote work-life balance? Evidence from the Wagelndicator Database. Leuven, Industrial Relations in Europe Conference.

Chieregato, E., 2020. A Work-Life Balance for All? Assessing the Inclusiveness of EU Directive 2019/1158. International Journal of Comparative Labour Law and Industrial Relations (ICL), 36(1), pp. 59-80.

Ciarini, A. \& Lucciarini, S., 2017. Collective Bargaining and Occupational Welfare in Italy. Economia \& lavoro, LI(2), pp. 143-156.

Ciccia, R. \& Sainsbury, D., 2018. Gendering Welfare State Analysis: Tensions between Care and Paid Work.. European Journal of Politics and Gender, 1(1-2), pp. 93-109.

Courtioux, P. \& Erhel, C., 2019. Is France converging or not? The role of industrial relations. In: D. Vaughan-Whitehead, ed. Towards Convergence in Europe. Institutions, Labour and Industrial Relations. Cheltenham: Edward Elgar, pp. 101-138.

Curzi, Y., Fabbri, T. \& Senatori, I., 2015. Getting Flexicurity Rights: New Ways to Reconcile Welfare, Flexibility and Competitiveness in a Post-Crisis Europe. Quaderni Fondazione Marco Biagi, 4(2), pp. 31-54. 
Da Roit, B. \& Gori, C., 2019. The transformation of cash-for-care schemes in European long-term care policies. Social Policy and Administration, 54(3), pp. 515-518.

Daly, M., 2002. Care as a Good for Social Policy. Journal of Social Policy, 31(1), pp. 251-.

de la Corte Rodriguez, M., 2018. EU Directives on maternity leave: A misleading social risk approach and its unsatisfactory effects on both mothers and fathers. European Labour Law Journal, 9(2), pp. 171-198.

De le Court, A., 2019. Collective Bargaining on Social Protection in the Context of Welfare State Retrenchment: The Case of Unemployment Insurance. In: J. Lopez Lopez, ed. Collective Bargaining and Collective Action. Labour Agency and Governance in the 21st Century?. Oxford: Hart Publishing, pp. 213-231.

Deakin, S., Fraser Butlin, S., McLaughlin, C. \& Polanska, A., 2015. Are litigation and collective bargaining complements or substitutes for achieving gender equality? A study of the British Equal Pay Act. Cambridge Journal of Economics, 39(2), pp. 381-403.

Directorate for Financial and Enterprise Affairs, Competition Committee, 2019. Competition Concerns in Labour Markets - Background Note (DAF/COMP (2019) 2). Paris: Organisation for Economic Co-Operation and Development.

Doherty, M. \& Franca, V., 2019. Solving the 'Gig-saw'? Collective Rights and Platform Work. Industrial Law Journal, 49(advance article).

Dorssemont, F. \& Lörcher, K. S. M., 2019. On the Duty to Implement European Framework Agreements: Lessons to be Learned from the Hairdressers Case. Industrial Law Journal, 48(4), pp. 571-603.

Dunlop, J. T., 1958. Industrial Relations Systems. New York: Holt.

Ebbinghaus, B., 2010. Unions and Employers. In: F. Castles, et al. eds. The Oxford Handbook of the Welfare State . Oxford: Oxford University Press, pp. 196-210.

Eurofund, 2017. Working time patterns for sustainable work, Publications Office of the European Union,. Brussels: Publication Office of the European Union.

Ewing, K., 2005. The Function of Trade Unions. Industrial Law Journal, 34(1), pp. 1-32.

Falkner, G., 1998. EU Social Policy in the 1990s: Towards a Corporatist Policy Community. London: Routledge.

Falkner, G., 2000. The Council or the social partners? EC social policy between diplomacy and collective bargaining. Journal of European Social Policy, 7(5), pp. 705-724.

Fineman, M., 2004. The Autonomy Myth. New York: The New Press.

Fraser, N., 2016. Contradictions of Capital and Care. New Left Review, 100(1), pp. 99-117.

Fuchs, G., 2013. Strategic Litigation for Gender Equality in the Workplace and Legal Opportunity Structures in Four European Countries. Canadian Journal of Law and Society, 28(2), pp. 189208.

Furåker, B. \& Larsson, B., 2020. Trade Union Cooperation in Europe. Patterns, Conditions, Issues. Cham: Pagrave Pivot.

GED/ILOAIDS, 2018. Care work and care jobs for the future of decent work. Geneva: International Labour Office.

González Begega, S. \& Aranea, M., 2018. The establishignof a European industrial relations system: Still under construction or chasing a chimera/. Employee Relations, 40(4), pp. 600-616. 
Hayter, S., Fashoyin, T. \& Kochan, T. K., 2011. Collective Bargaining for the 21st century. Journal of Industrial Relations, 53(2), pp. 225-247.

Hendy, J. \& Novitz, T., 2019 . The Holship Case. Industrial Law Journal, 47(2), pp. 315-335.

Herlofson, K. \& Brandt, M., 2019. Helping older parents in Europe: the importance of grandparenthood, gender and care regime. European Societies, Volume online first.

Herring, J., 2013. Caring and the Law. Oxford: Hart Publishing.

Hupkau, C. \& Perongolo, B., 2020. Work, care and gender during the Covid-19 crisis. London: Centre for Economic Performance.

International Labour Organisation, 2019. A quantum leap for gender equality : for a better future of work for all. Geneva: International Labour Office .

Isailovic, I., 2020. Gender Equality as Investment: EU Work-Life Balance and the Neoliberal Shift. SSRN.

Jessen, J. \& Waights, s., 2020. Effects of COVID-19 day care centre closures on parental time use: Evidence from Germany. Vox CEPR Policy Portal.

Johansson, C., 2019. A-kassan och den nya abretsmarknaden. In: L. Carlson, P. Herzfeld Olsson \& V. Pietrogiovanni, eds. Labour Law and the Welfare State. Uppsala: Författarna och lustus Förlag, pp. 169-186.

Keune, M. \& Marginsson, P., 2013. Transnational Industrial Relations as Multi-Level Governance: Interdependencies in European Social Dialogue. British Journal of Industrial Relations, 51(3), pp. 473-497.

Kongshøj Madsen, P., 2007. Flexicurity: A New Perspective on Labour Markets and Welfar States in Europe. Tilburg Law Review, 14(1 \& 2), pp. 57-79.

Kuhnle, S. \& Sanders, A., 2010. The Emergence of the Western Welfare State. In: F. Castles, et al. eds. The Oxford Handbook of the Welfare State. Oxford: Oxford University Press, pp. 61-80.

Lianos, I., Countouris, N. \& De Stefano, V., 2019. Re-thinking the competiton law/labour law interaction: Promoting a fairer labour market. European Labour Law Journal, 10(3), pp. 291333.

Marginson, P. \& Galetto, M., 2016. Engaging with flexibility and security: Rediscovering the role fo collective bargaining. Economic and Industrial Democracy, 37(1), pp. 95-117.

Marginsson, P., 2016. Work and Employment Relations in an Internationalized Economy. ILR Review, 69(5), pp. 1033-1055.

Meerten, H. v. \& Schmidt, E., 2017. Compulsory Membership of pension schemes and the free movement fo services in the EU. European Journal of Social Security, 18(1), pp. 118-140.

Natali, D., Keune, M., Pavolini, E. \& Seeleib-Kaiser, M., 2018 b. Sixty years after Titmuss: New findings on occupational welfare in Europe. Social Policy and Administration, 52(4), pp. 435448.

Natali, D., Pavolini, E. \& Vanhercke, B., 2018 a. Occupational Welfare in Europe: Risks, Opportunities and Social Partner Involvement. Brussels: European Trade Union Institute.

Nordling, H., 2015. State of the Union: The Applicability of Art 101(1) TFEU to Collective Bargaining Agreements after FNV Kunsten Media. Competition Law Journal, 14(1), pp. 37-48.

Nordström, A., 2015. A holistic approach to the provision of care: a key ingredient for economic independence. In: F. Bettio \& S. Sansonetti, eds. Visions for Gender Equality. Brussels: European Commission, pp. 45-48. 
OEDC, 2012. Closing the Gender Gap: Act Now. Paris: OECD Publishing.

Orloff, A. S., 2010. Gender. In: F. Castles, et al. eds. The Oxford Handbook of the Welfare State. Oxford: Oxford University Press, pp. 252-264.

Österle, A. \& Rothgang, H., 2010. Long-Term Care. In: F. G. Castles, S. Leibfried, H. Obinger \& C. Pierson, eds. The Oxford Handbook of the Welfare State. Oxford: Oxford University Press, pp. 378-390.

Pacolet, J., Bouten, R., Lanoye, H. \& Versieck, K., 2000. Social Protection for Dependency in Old Age. Abingdon: Ashgate.

Rubery, J. \& Hebson, G., 2018. Applying a gender lens to employment relations: Revitalisation, resistance and risks. Journal of Industrial Relations, 60(3), pp. 414-436.

Rubery, J. \& Koukidiakis, A., 2016. Closing the Gender Pay Gap. A Review of the Issues, Policy Mechanisms and International Evidence. Geneva: International Labour Office.

Rymkevich, O., 2015. Overview of the Findings of the Project. Quaderni Fondazzione Marco Biagi, $4(2)$, pp. 55-98.

Schiek, D., 2016. Europäische Kollektivvereinbarungen. In: W. Däubler, ed. Tarifvertragsgesetz mit Arbeitnehmerentsendegesetz. 4th ed. Baden-Baden: Nomos, pp. 264-312.

Schiek, D., 2017. Towards more Resilience for a Social EU - the Constitutionally Conditioned Internal Market. European Constitutional Law Review, 13(4), pp. 611-640.

Schiek, D. \& Gideon, A., 2018. Outsmarting the gig-economythrough collective bargaining - EU competition law as a barrier?. International Review of Law, Computers and Technology, 32(2), pp. 275-294.

Schiek, D., Oliver, L., Forde, C. \& Alberti, G., 2015. EU Social and Labour Rights and EU Internal Market Law. Brussels: European Parliament.

Schiek, D. \& Ulber, D., 2016. Tarifvertrag und nationales und supranationales Kartellrecht. In: W. Däubler, ed. Tarifvertragsgesetz. Baden-Baden: Nomos, pp. 193-204.

Simonnazzi, A., Ciampa, V. \& Villamaina, L., 2019. Italy: How could industrial relations help a return to economic and social convergence?. In: D. Vaughan-Whitehead, ed. Towards Convergence in Europe. Institutions, Labour Relations and Industrial Relations. Aldershot: Edward Elgar, pp. 205-249.

Traxler, F., 1996. European trade union policy and collective bargaining - mechanisms and levels of labour market regulation in comparison. Transfer, 2(2), pp. 287-297.

van Rie, T., Marx, I. \& Horemans, J., 2011. Ghent revisited: Unemployment insurance and union membership in Belgium and the Nordic countries. European Journal of Industrial Relations, 17(2), pp. 125-139.

Van Hiel, I., 2017. Between Registered and Precarious: Priority of Engagement for Dockworkers in European and International Law. In: K. Ahlberg \& N. Bruun, eds. The New Foundations of Labour Law. Brussels: Peter Lang, pp. 165-180.

Vandekerckhove, S., 2018. Inclusive Growth through Collective Bargaining (CAWIE research paper 3.1). Leuven: KU Leuven.

Vanherle, E., 2019. Compulsory Membership: Can it be valid in future and does it fit with freedom of services and competition law?. Leuven: KU Leuven, Faculty of Law.

Verhoeven, P., 2011. Dock Labor Schemes in the Context of EU Law and Policy. European Research Studies, XIV(2), pp. 149-166. 
Webb, S. \& Webb, B., 1902. Industrial Democracy. 2n ed. London: Longman.

Williams, J., 2002. "It's snowing down south": How to Help Mothers and Avoid Recycling the Sameness/Difference Debate. Columbia Law Review, 102(3), pp. 812-833.

Williams, J. C., Berdahl, J. \& Vandello, J., 2016. Beyond Work-Life "Integration". Annual Review of Psychology, 65(1), pp. 515-539.

Wujczyk, M., 2016. Constitutionalisation of Social Security Rights as the Way to a Social Justice State. In: A. Egorov, ed. The Right to Social Security in the Constitutions of the World. Broadening the moral and legal space for social justice. Volume I Europe. Geneva: International Labour Organisation, pp. 1-6.

Yerkes, M. \& Tijdens, K., 2010. Social risk protection in collective agreements: evidence from the Netherlands. European Journal of Industrial Relations, 16(4), pp. 369-383. 


\section{Table of Contents}

$\begin{array}{ll}\text { I. Introduction } & 1\end{array}$

II. Context 2

1. "Work life balance", unpaid care work and gender equality in employment 2

2. Gender equality policy and collective bargaining 3

3. Occupational social security as a field for collective bargaining 4

4. The contribution beyond the context 4

III. Engaging in unpaid care work as a social security risk 5

1. Defining social security risk 5

2. The care risk 5

IV. Collective bargaining and the care risk $\quad 6$

1. Collective bargaining and social security 6

2. Collective bargaining and the care risk $\quad 7$

V. Care risk and collective bargaining under EU Law $\quad 8$

1. Potential of EU level collective bargaining for care institutions 8

2. Steps towards care institutions via collective agreements under national law 8

3. Potential barriers under EU law 9

a) Collectively agreed common institutions in EU economic law-current and evolving case law 9

b) How does this apply to establishing care institutions in collective agreements? 12

c) Alternative future directions $\quad 13$

$\begin{array}{ll}\text { VI. Conclusion } & 14\end{array}$

$\begin{array}{ll}\text { Bibliography } & 15\end{array}$ 